\title{
JAK OCENIĆ WSPÓŁCZESNE MIESZKANIE? PRÓBA ZDEFINIOWANIA KRYTERIÓW WARTOŚCIUJĄCYCH JAKOŚĆ UŻYTKOWĄ WSPÓŁCZESNYCH POLSKICH MIESZKAŃ
}

\author{
Maciej Kłopotowski \\ Zespół Dydaktyczny Architektury Krajobrazu, Katedra Ochrony i Kształtowania Środowiska, \\ Wydział Budownictwa i Inżynierii Środowiska, Politechnika Białostocka \\ Team Educational Landscape Architecture Department and Environmental Protection, \\ Department of Civil and Environmental Engineering, University of Bialystok \\ e-mail: m.klopotowski@pb.edu.pl
}

\begin{abstract}
Streszczenie. W artykule zaprezentowano aktualny problem - oceny jakości użytkowej współczesnych mieszkań. Problematyka ta została naświetlona na tle doświadczeń projektowych i realizacyjnych ostatnich kilkudziesięciu lat. Wobec braku zobiektywizowanych metod oceny oraz wartościowania omawianych zagadnień autor wskazuje kryteria mogące stać się podstawą takich probierzy i ocen.
\end{abstract}

Słowa kluczowe: mieszkanie, jakość przestrzeni, jakość mieszkania, użyteczność mieszkania

\section{WSTĘP}

Współczesne środowisko mieszkaniowe niemalże w całości realizowane jest w systemie inwestycji developerskich. Poszczególne realizacje powstają w oparciu o szereg uwarunkowań, w tym zapisy miejscowych planów zagospodarowania przestrzennego oraz przepisy wynikające $\mathrm{z}$ warunków technicznych. Odrębnym czynnikiem, wpływającym na ich ostateczny kształt, jest doświadczenie zawodowe inwestora (developera), który wielokrotnie uzależnia preferencje inwestycyjne i założenia projektowe od aktualnych „,zainteresowań” czy „upodobań" przyszłych nabywców mieszkań. Oczekiwania te są z kolei szczególnie podatne na trendy, kształtujące się pod wpływem publikacji prasowych - w tym pseudofachowej prasy kolorowej, oraz telewizyjnych - w tym rozpropagowywanych poprzez popularne seriale i programy telewizyjne. W procesie kształtowania środowiska mieszkaniowego uczestniczą wreszcie jego bezpośredni projektanci - architekci. Ich osobisty wpływ na ostateczny kształt projektowanych mieszkań, budynków i ich zespołów oraz całych osiedli jest pochodną narzuconych odgórnie wymogów, ale również przygotowania zawodowego i własnego doświadczenia projektowego.

Należy jednoznacznie stwierdzić, iż brak jest współcześnie narzędzi weryfikujących jakość tak kształtowanej przestrzeni mieszkaniowej (mieszkań, domów, ich zespołów i osiedli), nad którą kontrolę (ocenę i wartościowanie) zdają się pełnić całkowicie do tego nie przygotowani inwestorzy (nabywcy mieszkań). Stan ten skłania do zadania pytania o jakość środowiska mieszkaniowego, powstającego w oparciu o tak mało stabilne i zdefiniowane uwarunkowania.

Celem badań, zaprezentowanych w niniejszym opracowaniu, jest podjęcie próby zdefiniowania cech, mogących stać się podstawą budowy narzędzia pomiarowego, pomocnego w ocenie jakości środowiska mieszkaniowego. Na potrzeby niniejszej publikacji szerokie pojęcie środowiska mieszkaniowego ograniczone zostało do ram pojedynczego lokalu mieszkalnego. Podjęto tym samym próbę wartościowania cech wpływających na jakość najbliższej człowiekowi przestrzeni prywatnej, mającej największy wpływ na komfort życia. Prezentowane tu wyniki badań stanowią fragment wieloletnich analiz prowadzonych przez autora we współpracy z innymi architektami, urbanistami, osobami zajmującymi się obrotem i zarządzaniem nieruchomościami oraz matematykami i informatykami (zajmującymi się zagadnieniami analiz 
wielokryterialnych), związanymi zawodowo z kształceniem na kierunku studiów Gospodarka Przestrzenna w Politechnice Białostockiej.

Prezentowane metody badawcze są autorskie i bazują głównie na ocenach eksperckich, co wynika $\mathrm{z}$ braku aktualnie obowiązujących kryteriów obiektywizujących analizowane zagadnienia, w tym publikowanych badań prowadzonych przez inne ośrodki i zespoły naukowe.

Podstawę prowadzonych analiz stanowi tym samym wiedza i doświadczenie zawodowe autora, które ukształtowane zostały w trzech odrębnych „epokach” rzeczywistości projektowej. Odpowiadają one kolejnym etapom historii współczesnego mieszkalnictwa, a związane są z różnymi zasadami kształcenia i odmiennym wartościowaniem priorytetów projektowych. Po pierwsze w okresie przed rokiem 1989, a więc w czasie obowiązywania tak zwanych „normatywów mieszkaniowych” związanych z upaństwowionym systemem dystrybuowania mieszkań a mających gwarantować ich jakość przestrzenną. Był to okres rozbudowanego publikowania fachowej literatury poruszającej omawianie zagadnienia. Były to zarówno publikacje książkowe jak i artykuły publikowane w prasie branżowej (głównie czasopiśmie „Architektura”). I po drugie po roku 1989 gdy działania z obszaru realizacji zabudowy mieszkaniowej przejęli developerzy zaś z zakresu ich projektowania indywidualni architekci . Ich wiedza wywodziła się z doświadczeń przeszłości oraz wyobrażenia zasad funkcjonowania tak zwanego „świata zachodniego". Nowa architektura mieszkaniowa miała być manifestem odcięcia się od post PRL-owskiej przeszłości. I po trzecie czasów współczesnych, gdy zarówno developerzy jak i projektanci stanowią grupę, która w wielu obszarach funkcjonowania jest wolna do PRL-owskich doświadczeń (wielokrotnie wynika to wieku w/w osób). Ich kreacja współczesnego świata - w tym środowiska mieszkaniowego ma stanowić odpowiedź na współczesność i nowe potrzeby oraz możliwości. Fakt niekorzystania z wypracowanych w przeszłości wzorców wynika z powszechnej ignorancji („,my tworzymy tu i teraz” - nasze realia, „my wiemy czego potrzebujemy” - intuicja), niewiedzy („nie ma książek na ten temat a czasopisma pokazują jedynie ilustracje”) i braku świadomości ich wartości („stare jest złe”). Ponadto szerokiego dostępu do wiedzy na temat inwestycji prowadzonych w tym samym czasie co zapewnia Internat. Tym samym ilość (popularność) poszczególnych rozwiązań narzuca nam trend (powielanie aktualnych wzorców, porównywanie się z nimi).

\section{UZASADNIENIE PODJĘCIA BADAŃ I ICH ZAKRES}

Normatyw mieszkaniowy jest jednoznacznie utożsamiany z jakością przestrzenną i użytkową mieszkań realizowanych w PRL. Jego podstawą była powierzchnia użytkowa, która każdorazowo skorelowana była z zakładaną ilością mieszkańców. Proces projektowania mieszkań polegał tym samym na „wykazaniu”, że rodzina o określonej strukturze „da radę” mieszkać w lokalu o zdefiniowanej (zwykle uważanej za zbyt skromną ${ }^{1}$ ) powierzchni użytkowej. Na uwagę zasługuje fakt, iż istotny element tych działań oparty był na pracach badawczych z zakresu ergonomii i wyposażenia mieszkań. Przywołać tu należy chociażby prace badawcze, z lat pięćdziesiątych i sześćdziesiątych, profesor Haliny Skibniewskiej, które zaowocowały budową „mieszkania elastycznego” na terenie Osiedla Sady Żoliborskie w Warszawie. Mieszkanie to, to swoisty mechanizm zmieniający się wraz z potrzebami użytkowymi jego mieszkańców. Każdorazowo nowy wariant owego mechanizmu odpowiada na zdefiniowane potrzeby użytkowe, które to z kolei opracowano w oparciu o racjonalne przesłanki zdefiniowane na podłożu ergonomii. Poczatek lat 70. i powszechne zafascynowanie działaniem systemowym doprowadziło do typizacji i schematyzmu rozwiązań mieszkań. Trwałym przestrzennie efektem

1 Powierzchnia użytkowa mieszkań określona w tak zwanych normatywach powierzchniowych była zdecydowanie niższa od analogicznych wzorców obowiązujących w krajach tak zwanej Europy Zachodniej. Na przykład w Karcie kolońskiej z roku 1971 mieszkanie dla trzy osobowej rodziny wskazywano jako 61,5 $\mathrm{m}^{2}$ plus powierzchnia komunikacji, gdy w roku $1974 \mathrm{w}$ polskich normatywach jako $44-46 \mathrm{~m}^{2}$. 
tych działań stały się systemy prefabrykacji (w tym między innymi bardzo popularny OW-T). Ich powszechne stosowanie zaowocowało dziesiątkami tysięcy realizacji identycznych budynków i mieszkań rozsianych w całym kraju. Podkreślić należy przy tym, że świadomość tych działań skłaniała ich projektantów do staranności w projektowaniu rozwiązań funkcjonalnych. Pozytywne doświadczenia w tym zakresie, będące skutkiem realizacji specjalnych programów rządowych, jak chociażby PR-5, a w jego ramach budowa mieszkań projektowanych przez Bohdana Jana Jeziorskiego (z zespołem) na terenie Zamościa - Nowe Miasto czy profesor Hanny Adamczewskiej - Wejchert na osiedlu modelowym w Tychach, stanowią niewątpliwie wyjątek w omawianym procesie. Realizacja zadań inwestycyjnych związanych z budową mieszkań, co spoczywało w tym okresie na barkach państwa, zaowocowało ciągłą pogonią za modami i tendencjami europejskimi. Rozdźwięk w tym zakresie pogłębiał się wraz z pogarszającą się sytuacja gospodarczą. Wspomnieć należy iż niewprowadzony z powodów gospodarczych (brak możliwości finansowych realizacji) w roku 1985 nowy normatyw powierzchniowy mieszkań powielał zalecenia opracowane w Karcie kolońskiej z roku 1971. Analiza wymienionych powyżej (i wielu innych) realizacji mieszkaniowych(z lat 1945-1989) wskazuje na następujące cechy mieszkań zrealizowanych w PRL:

- zgodność powierzchniowa (mieszkań i poszczególnych pomieszczeń) z obowiązującym normatywem skorelowana z ilością mieszkańców, co owocowało wykazaniem projektowym możliwości pomieszczenia odpowiedniej ilości miejsc przeznaczonych do snu (łóżek) - swoista ergonomiczna staranność (modelowość) aranżacji rzutu mieszkania, pozwalająca na jednoznaczne odczytanie informacji, że wszystkie niezbędne elementy wyposażenia „zmieszczą się” a korzystanie z nich „będzie możliwe".

Oczywistym pozostają przy tym takie aspekty projektowe jak nasłonecznienie i przewietrzanie mieszkania, które to regulowały odrębne przepisy. Analizując tak realizowany proces projektowy należy jednoznacznie stwierdzić, że realizowany był on według schematu: wytyczne (założenie projektowe) - normatyw (przepis) - mieszkanie (ergonomia) - budynek $($ technologia $=$ system prefabrykacji), osiedle (jednostka usługowa) - dzielnica $($ system organizacji przestrzeni) - miasto (efekt realizacji założeń projektowych). W schemacie tym, który stanowi zracjonalizowany proces, wyeliminowano pojęcie ARCHITEKTURA, które zastąpione zostało BUDOWNICTWEM MIESZKANIOWYM.

W ciągu ostatniego ćwierćwiecza, zupełnie nowe, wolnorynkowe, mechanizmy gospodarcze wpływają na to jak?, gdzie?, za ile? i dlaczego? mieszkamy. Konkretna realizacja tych aspektów niejednokrotnie świadczy o naszej zamożności, statusie zawodowym ale również pozycji społecznej czy otwartości na współczesny świat (rozumieniu i akceptowaniu go, uczestniczeniu w toczących się przemianach). Wpływ na to ma również nasz wiek. Doświadczenia te znajdują swe odzwierciedlenie w realizacjach mieszkaniowych. Rynek developerski oferuje ogromny wachlarz rozwiązań, z których większość zaprojektowana została przy zdecydowanie innych priorytetach użytkowych niż przytaczane powyżej. Stwierdzić należy, iż zasady, którymi kierują się developerzy i projektanci współcześnie kształtowanego środowiska mieszkaniowego są zupełnie inne (uległy one niezdefiniowanemu dotychczas i niekontrolowanemu przewartościowaniu). Inwestor działa według nowego (własnego, współczesnego) schematu: developer (inwestor, firma, zysk) - własność (działka) - przepisy (miejscowy plan zagospodarowania przestrzennego, warunki techniczne) - budynek (powierzchnia do sprzedania) - mieszkanie (wynik działań projektowych) - miasto (zespół działań developerów).

2 Podkreślić należy, że doświadczenia te kontynuowane były do końca istnienia PRL zaś analiza rzutów mieszkań z poszczególnych okresów wskazują na istnienie procesu wykazującego wzrost standardu użytkowego projektowanych wówczas mieszkań. Wraz ze zwiększającym się normatywem powierzchniowym mieszkania poszczególnych kategorii zwiększały swe strefy dzienne i program użytkowy kuchni, program strefy rodziców i dzieci, ilość i standard wyposażenia pomieszczeń sanitarnych i gospodarczych. W rezultacie mieszkanie większe powierzchniowo oferowało bogatszy program funkcjonalny. 
Jego zadaniem jest zysk. W procesie tym architekt staje się osobą odpowiedzialną za kształtowanie „swego" wizerunku poprzez „swoje” realizacje - najczęściej utożsamiane z formą architektoniczną projektowanego obiektu. Mieszkanie w tym procesie staje się towarem, który ma zaspokoić potrzeby odbiorcy. Jego jakość zostaje pozostawiona do oceny nieprzygotowanemu nabywcy, który z założenia wierzy, że oferowany jest mu produkt pełnowartościowy, optymalny od strony użytkowej, przy zachowaniu rozsądnej korelacji powierzchni użytkowej z ilością pomieszczeń oraz możliwością ich użytkowania. Tak traktowany klient spośród wielu oferowanych produktów zawsze wybierze „produkt bezpieczny” - taki, który będzie się wpisywał w masowy trend (przypominał najbardziej popularne, najczęściej rozpowszechniane w obecnym czasie).

Analiza tak projektowanych współczesnych mieszkań prowokuje do podjęcia próby ich oceny, przy użyciu zobiektywizowanych kryteriów, a tym samym opracowania narzędzia umożliwiającego ich wartościowanie. Narzędzia, które może być przydatne zarówno nabywcom jak i sprzedawcom poszczególnych nieruchomości. Powinno ono również być przydatne developerom, oceniającym oferowane im rozwiązania architektoniczne, ale również opracowującym szczegółowe wytyczne (założenia projektowe). Ten ostatni z aspektów zdaje się być szczególnie istotny $\mathrm{w}$ zestawieniu $\mathrm{z}$ analizowanymi ofertami rynku nieruchomości. Niemalże standardem staje się być całkowite oderwanie programu użytkowego mieszkania od jego wielkości (a więc potencjału użytkowego). Zagadnienie to doskonale egzemplifikuje zamieszczony poniżej przykład ,70 $\mathrm{m}^{2}$ " $\mathrm{w}$ dwóch wariantach. W pierwszym jest to pięć pokoi + odrębna oświetlona światłem dziennym kuchnia i węzeł sanitarny. Poszczególne pomieszczenia w tym wariancie można połączyć i stworzyć tak zwaną „open space” (Rys. 1.). I drugi, gdzie świadomie zaprojektowano dużą otwartą (niepodzielną ze względu na brak okien) cześć dzienną z wbudowaną w nią ciemną kuchnią oraz sypialnię, zespół garderób i węzeł sanitarny (Rys. 2.). Oba warianty powstały w różnym czasie (dzieli je okres ponad czterdziestu lat) ale również adresowane są do różnych użytkowników.

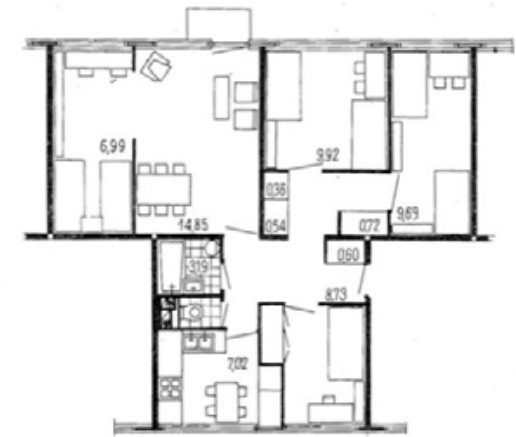

Ryc 1. Mieszkanie o powierzchni użytkowej 72, $45 \mathrm{~m}^{2}$ realizowane w systemie OWT -67

Fig. 1. The flat, usable area $72,45 \mathrm{~m}^{2}$, carried out in the system OWT -67

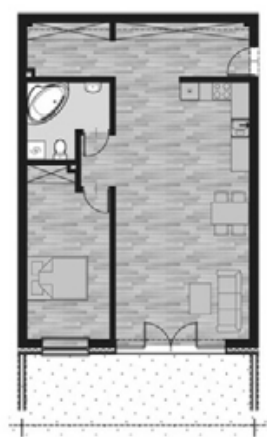

Ryc. 2. Mieszkanie o powierzchni użytkowej $70,5 \mathrm{~m}^{2}$ realizowane w systemie developerskim (Białystok 2015)

Fig. 2. The flat, usable area $70.5 \mathrm{~m}^{2}$, carried out in the development system (Bialystok 2015)

Prezentowane w dalszej części niniejszego opracowania wyniki badań dotyczą wyłącznie jednego $\mathrm{z}$ analizowanych aspektów - a mianowicie jak? mieszkać. W całości odnosi się on do zagadnień bezpośrednio związanych z mieszkaniem. Z uwagi na ograniczone ramy opracowania nie zostaną $\mathrm{w}$ nim przedstawione zagadnienia związane z problematyką:

- gdzie? - która analizowana jest w podziale na takie aspekty jak: lokalizacja (prestiż miejsca, dostępność komunikacyjna, odległość miejsca pracy, dostępność usług, dostępność terenów rekreacyjnych, itd. ), typ budynku (rodzaj zabudowy, wysokość zabudowy, 
sposób zagospodarowania otoczenia budynku, usługi związane z budynkiem, garaże i parkingi, itd. ), usytuowanie w budynku (położenie w konkretnej klatce schodowej, położenie na konkretnej kondygnacji, widok z okna, itd. ), budynek (rozwiązania techniczno - materiałowe),

- za ile? - która związana jest z indywidualnymi finansowymi możliwościami inwestorów,

- dlaczego? - która stanowi tak zwany nieobiektywny czynnik ludzki, który to opiera się na grze emocji, wrażeń oraz dotychczasowych indywidualnych doświadczeniach życiowych. Obejmuje on również aspekt budowy własnego wizerunku (moje mieszkanie świadczy o mnie, np.: wyłącznie nowe), indywidualnej oceny atrakcyjności konkretnego mieszkania (na przykład lubimy i w związku z tym preferujemy: duże okna, schody, zaskakujące rozwiązania przestrzenne, charakterystyczne rozwiązania wnętrzarskie, itp.) oraz szereg zagadnień związanych $\mathrm{z}$ funkcjonowaniem $\mathrm{w}$ społeczeństwie ( $\mathrm{w}$ tym w rodzinie, np.: mieszkanie blisko babci, pracy, i itd. ).

Wszystkie $\mathrm{z}$ w/w zagadnień $\mathrm{w}$ różnym stopniu wpływają na decyzje inwestycyjne. Ich zracjonalizowanie możliwe jest w bardzo ograniczonym zakresie, gdyż w znacznym stopniu zależne jest od wieku i statusu finansowego inwestorów. Niemalże niemożliwe jest racjonalizowanie „dlaczego?” gdyż wymyka się ono z obiektywnych ram. Jednocześnie doświadczenie analiz decyzji inwestycyjnych pozwala stwierdzić, iż owo nieracjonalne „dlaczego?” niejednokrotnie staje się jeśli nie podstawą to argumentem przeważającym w podejmowaniu tych decyzji.

\section{KRYTERIA OCENY JAKOŚCI MIESZKANIA}

Kryteria oceny jakości mieszkania oparto na podziale jego cech oraz parametrów na trzy grupy:

- możliwe do oceny w oparciu o obowiązujące przepisy Prawa Budowlanego,

- możliwe do oceny i wartościowania w oparciu o założenia teoretyczne związane z ksztaltowaniem przestrzeni mieszkań,

- możliwe do oceny i wartościowania w oparciu o założenia teoretyczne związane z ergonomią użytkowania przestrzeni.

\section{PRAWO BUDOWLANE}

Założono, iż mieszkanie musi spełniać wszystkie z warunków określonych w przepisach Prawa Budowlanego. Podzielono je przy tym na trzy grupy oczywiste, niezbędne i mogące podwyższyć ocenę mieszkania. Za oczywiste uznano, iż mieszkanie spełnia wymogi związane z wydzieleniem przeciwpożarowym, ewakuacją, minimalną wielkością otworów okiennych i drzwiowych, wentylacją, nasłonecznieniem i minimalnym wyposażeniem sanitarnym. Za niezbędne uznano zachowanie gabarytów, które w warunkach technicznych zostały sparametryzowane, w tym: minimalna powierzchnia jednego pokoju $\left(16 \mathrm{~m}^{2}\right)$, minimalna szerokość wydzielonej kuchni (180 lub $240 \mathrm{~cm}$ - w zależności od wielkości mieszkania), minimalna szerokość pokoju jednoosobowego $(210 \mathrm{~cm})$ i dwuosobowego $(270 \mathrm{~cm})$. Założono przy tym, iż w mieszkaniu dwu i więcej pokojowym jedna $\mathrm{z}$ sypialni to tak zwana sypialnia główna (sypialnia gospodarzy, rodziców) i pomieszczenie to musi spełniać warunki zdefiniowane dla pokoju dwuosobowego.

Za mogące podwyższyć ocenę mieszkania uznano jego cechy i gabaryty, które są wymiernie zobiektywizowane i nie mogą ulec zmianie w wyniku przebudowy (przearanżowania) mieszkania. Uznano, iż należy do nich zaliczyć: wysokość mieszkania (minimum to $250 \mathrm{~cm}$ ), nasłonecznienie (nawet gdy przepisy tego nie wymagają), atrakcyjność strefy zewnętrznej mieszkania, która występuje w formie mini ogródka, tarasu lub balkonu. W obszarze tym 
wyodrębniono również problem przewietrzania mieszkania, uznając za wadę jednostronne rozwiązanie okien, mimo zastosowania wentylacji mechanicznej (na co w/w przepisy pozwalają).

\section{KSZTAŁTOWANIE PRZESTRZENI}

Kształtowanie przestrzeni wewnętrznej mieszkania zależne jest od jego wielkości oraz ilości osób, które mają w nim mieszkać. Doświadczenia przeszłości wskazują jednak jednoznacznie na możliwość wprowadzenia gradacji stosowanych rozwiązań, zaś prowadzone analizy usystematyzowane zostały w dwóch poziomach: ogólnym - odnoszącym się do całego mieszkania i szczegółowym - odnoszącym się do poszczególnych zdefiniowanych stref funkcjonalnych.

Na podstawie teorii projektowania mieszkań, ze względu na rozwiązania funkcjonalne, wyodrębnić można następujące ich układy przestrzenne: amfiladowe, open space, rozkładowe, $\mathrm{z}$ podziałem na strefy funkcjonalne, cyrkulacyjne, dwupoziomowe (mezonet).

Układy amfiladowe związane są z projektowaniem pokoi przejściowych i są charakterystyczne dla rozwiązań historycznych. Układ ten można odnaleźć w tradycyjnych XIX wiecznych kamienicach oraz tak zwanych inteligenckich mieszkaniach okresu międzywojennego. Wówczas amfiladowy sposób łączenia pomieszczeń miał pozwalać na ich dowolne (wielofunkcyjne, zmienne w czasie) użytkowanie. Obecnie układ ten w swej tradycyjnej formie niemalże nie jest stosowany. Nie pozwala bowiem na dyskretne indywidualne użytkowanie poszczególnych (przejściowych) pomieszczeń a indywidualizacja przestrzeni stała się w ciągu ostatnich kilkudziesięciu lat wyznacznikiem tak zwanego „dobrego projektowania”.

Układ open space to współcześnie spopularyzowana forma układu amfiladowego, w którym rolę pomieszczenia przejściowego stanowi pokój dzienny (niekiedy rozbudowana „otwarta" strefa pokoju dziennego). Staje się on w takim układzie specyficznym holem, który zostaje zdominowany przez funkcje komunikacyjne. Pomieszczenie to rzadko kiedy pozwala na swobodne użytkowanie go przez mieszkańców. Powstała w taki sposób przestrzeń podlega ciągłej kontroli, co nie wpływa pozytywnie na komfort jej użytkowania. Open space sprawdza się w mieszkaniach o dużej powierzchni, w których możliwe jest wydzielenie z niej aneksów (telewizyjnego, wypoczynkowego, itp.), zwłaszcza takich, które nie będą widoczne z obszaru bezpośrednio związanego z wejściem do mieszkania.

Układ rozkładowy to modernistyczny model kształtowania przestrzeni mieszkania, w którym poszczególne pomieszczenia (pokoje, kuchnia, łazienka) dostępne są z korytarzy lub holi. Im większe jest mieszkanie, tym bardziej skomplikowany staje się w ich układ komunikacyjny i tym większego znaczenia nabiera konieczność grupowania pomieszczeń o zbliżonej lub uzupełniającej się funkcji. Układ ten świetnie sprawdza się w mieszkaniach małych. W mieszkaniach dużych częstokroć wywołuje kolizje komunikacyjne. W ocenach fachowców, niezależnie od swych mankamentów, jest on oceniany zdecydowanie wyżej niż zaprezentowane powyżej układy amfiladowe i ich współczesne odpowiedniki.

Układ z podziałem na strefy funkcjonalne to rozbudowany system, w którym przestrzeń mieszkania podzielona została na strefy: dzienną związaną z reprezentacyjno - wspólną częścią mieszkania oraz nocną - związaną z pokojami prywatnymi, przy czym część nocna może dodatkowo zostać podzielona na część dzieci i rodziców a całość układu może zostać rozbudowana o dodatkowe pokoje o przeznaczeniu mieszkalnym (goście) lub zawodowym (pokój do pracy, gabinet). Układ strefowy związany jest również z rozbudową programu pomieszczeń sanitarnych - im bardziej skomplikowany tym ich więcej. Najczęstszym rozwiązaniem jest projektowanie WC w części dziennej oraz odrębnych łazienek dla dzieci i rodziców. W bardzo dużych mieszkaniach zdecydowanie odrębnym zasadom podlega projektowanie kuchni 
i pomieszczeń gospodarczych oraz służbówki ${ }^{3} \mathrm{z}$ nimi związanych. Mieszkania o takich układach w Polsce popularyzowane były od drugiej połowy lat 70 .

Układ cyrkulacyjny realizowany jest zwykle jako rozbudowa układu strefowego i polega na kształtowaniu komunikacji wewnątrz mieszkania w sposób umożliwiający „krążenie” po nim. Układ ten prowadzony jest najczęściej na osi: strefa wejścia - część dzienna - strefa rodziców - strefa dzieci - strefa wejścia. Zaś kolejne przechodnie pomieszczenia to: hall wejściowy - pokój dzienny - korytarz - hall wejściowy. Cyrkulacja prowadzona jest przy tym wokół pomieszczeń położonych w środku rzutu mieszkania (nie wymagających doświetlenia). Są nimi: WC, łazienka, pralnia, pomieszczenia gospodarcze, garderoby. W przestrzeni pełni on funkcje psychologiczne i daje iluzoryczne wrażenie zwiększenia powierzchni mieszkania. Po takim mieszkaniu „można chodzić” i wydaje się ono większe niż jest w rzeczywistości. Mieszkania o takim właśnie układzie przestrzennym preferowane były w Polsce w pierwszej połowie lat 80 ., niestety uwarunkowania ekonomiczne tego okresu nie pozwoliły na ich popularyzowanie.

Układ dwupoziomowy, którego zapożyczona z języka francuskiego nazwa mezonet to kolejny rozbudowany układ z podziałem na strefy funkcjonalne. Poszczególne z nich lokowane są na różnych kondygnacjach. Najczęściej na poziomie podstawowym lokowana jest część dzienna, kuchnia i WC oraz w zależności od wielkości mieszkania pokoje dodatkowe lub/i strefa rodziców, zaś na drugiej kondygnacji strefa sypialni i pomieszczeń sanitarnych dzieci oraz rodziców (jeśli nie zostały zlokalizowane na poziomie podstawowym). Układ dwupoziomowy wewnątrz mieszkania ma odwzorowywać tradycyjny podział zapożyczony $\mathrm{z}$ domu jednorodzinnego - ma stanowić jego namiastkę. W Polsce układ ten był stosowany w latach 60. i 70., w mieszkaniach zlokalizowanych w budynkach o galeriowym rozwiązaniu komunikacji wspólnej. Od początku lat 90. przeniesiony został do budynków klatkowych i zdominował rozwiązania mieszkań zlokalizowanych na najwyższych kondygnacjach ${ }^{4}$.

Zaprezentowane powyżej kryteria trudne są do zastosowania w odniesieniu do mieszkań jednopokojowych oraz jednoprzestrzennych typu studio. Ich ocena w zakresie kształtowania przestrzeni powinna być prowadzona indywidualnie ze szczególnym podkreśleniem walorów funkcjonalnych w odniesieniu do mieszkań małych oraz przestrzennych w odniesieniu do mieszkań dużych. Wielokrotnie nie ma również zastosowania $\mathrm{w}$ odniesieniu do tak zwanych penthous 'ów - dużych luksusowych mieszkań zlokalizowanych na ostatnich kondygnacjach budynków. Projektowane są one jako skomplikowane układy przestrzenne z dużym programem pomieszczeń dziennych i obsługujących (zamknięte kuchnie, pokoje gospodarcze, służbówki).

Analiza szczegółowa poszczególnych części (stref) mieszkania powinna być prowadzona w podziale na: część wejściową, część dzienną i kuchnię, strefę rodziców, strefę dzieci, strefę gospodarcza oraz ewentualną strefę programu dodatkowego.

Część wejściowa to zespół pomieszczeń zlokalizowanych w bezpośrednim sąsiedztwie drzwi wejściowych mieszkania. Zwykle jest to hall lub korytarz, które powinny przestrzennie w układzie mieszkania być tak ulokowane, by korzystanie $\mathrm{z}$ nich nie ingerowało $\mathrm{w}$ inne jego części. Dobrze zaprojektowana strefa wejścia pozwala na przyjęcie „listonosza” lub „sąsiadki”

3 Służbówka - pomieszczenie mieszkalne przeznaczone dla zatrudnionej na stałe pomocy domowej. W okresie międzywojennym w polskich domach z mieszkaniami ,inteligenckimi” lokalizowane było w okolicach kuchni. Obecnie, w bardzo dużych mieszkaniach, wzorem rozwiązań europejskich służbówka lokalizowana jest w obrębie strefy wejścia. Współczesna służbówka częstokroć wyposażona jest w odrębny węzeł sanitarny i niezależne wejście.

4 Lokalizacja, w latach 90., na najwyższych kondygnacjach budynków mieszkalnych mieszkań dwupoziomowych wynikała z prowadzonej przez developerów swoistej gry mającej „obejść” obowiązujące przepisy prawa budowlanego związane z koniecznością stosowania dźwigów osobowych. Mieszkania dwupoziomowe pozwalały na budowę wyższych budynków bez ich zastosowania. 
w taki sposób, że osoby te nie będą miały wglądu w dalszą część mieszkania. W strefie tej powinny znaleźć się szatnia i garderoba przeznaczone odpowiednio dla gości i mieszkańców oraz WC. Zasadne wydaje się być badanie lokalizacji wejścia do tego pomieszczenia a preferowanie rozwiązanie to takie, które gwarantują jego niewidoczność z obszaru jadalni (miejsc przy stole) oraz strefy wypoczynkowej (siedzisk zlokalizowanych w przestrzeni dziennej). Wejście to nie powinno krępować korzystania $z$ toalety.

Część dzienna i kuchnia to część mieszkania, w której spotykają się wszyscy domownicy oraz przyjmują swych gości. Jej lokalizacja wewnątrz mieszkania powinna gwarantować bezpośrednie powiązanie ze strefą wejścia przy jednoczesnej izolacji (lub jej opcjonalnej możliwości) aneksów: jadalnego i wypoczynkowego. W strefie tej zlokalizowana jest jadalnia, która powinna być zlokalizowana na granicy przestrzeni wypoczynkowej i kuchni (możliwie blisko kuchni). Kuchnia, zlokalizowana w tej części mieszkania, często bywa lokalizowana w przestrzeni pokoju dziennego - co uniemożliwia jej wydzielenie (zasłonięcie), jako pomieszczenie, które w zależności od preferencji użytkownika może zostać połączone $\mathrm{z}$ pokojem oraz całkowicie od niego oddzielone. Sposób powiązania pomieszczenia kuchni z pokojem dziennym generuje różne sposoby rozwiązania miejsca spożywania posiłków, przy czym rozwiązania wzorcowe to takie, w którym w kuchni zlokalizowane jest miejsce spożywanie śniadań i tak zwanych „szybkich” posiłków, zaś w przestrzeni pokoju dziennego miejsce do spożywania posiłków uroczystych (związanych na przykład z uroczystościami rodzinnymi i świętami). Pierwsze z tych miejsc powinno gwarantować możliwość wygodnego użytkowania w tym samym czasie przez wszystkich mieszkańców, zaś drugie powinno gwarantować możliwość zgromadzenia przy rozłożonym stole kilku/kilkunastu osób.

Strefa rodziców zwana również sypialnią główną w przestrzeni mieszkalna powinna być dostępna z przestrzeni komunikacji, powiązanej ze strefą wejściową (co jest możliwe w mieszkaniach o układzie rozkładowym, z podziałem na strefy funkcjonalne, cyrkulacyjnym lub dwupoziomowym) lub z części dziennej (co jest możliwe w mieszkaniach o układzie amfiladowym, open space, oraz w szczególnych przypadkach w mieszkaniach o układzie cyrkulacyjnym i dwupoziomowym). W jej skład wchodzą sypialnia, łazienka (określana mianem łazienki głównej - najlepszej, najlepiej wyposażonej, w mieszkaniu) oraz garderoba lub zestaw szaf ubraniowych. Strefa ta powinna być zlokalizowana w taki sposób by gwarantować jej użytkownikom maksimum prywatności.

Strefa dzieci, w skład której wchodzą pokoje indywidualne dzieci, ich garderoba (garderoby) i łazienka (lub łazienki) powinna być zlokalizowana możliwie blisko strefy wejścia i być z nią bezpośrednio połączone przestrzenią komunikacji wewnętrznej, przy czym komunikacja ta nie powinna prowadzić przez inne strefy mieszkania. Wejście do tej strefy powinno być projektowane w sposób umożliwiający wejście z pominięciem wglądu w część dzienną oraz uniemożliwiający jego kontrolowanie z tej strefy.

Strefa gospodarcza to zespół pomieszczeń (szaf gospodarczych) ulokowanych w różnych częściach mieszkania i związanych $\mathrm{z}$ jego prawidłowym funkcjonowaniem. W jej skład wchodzą: spiżarnie, pralnie, pomieszczenia o charakterze porządkowym i magazynowym (np.: przechowywanie walizek, ozdób świątecznych i itp.). Poszczególne funkcje mogą być lokowane w pomieszczeniach (lub sąsiedztwie) kuchni, łazienek, garderób, korytarzy, holi wejściowych.

Strefę programu dodatkowego, w skład której wchodzą pokoje gościnne (często z własnymi łazienkami) oraz pokoje do pracy (gabinety) powinny być lokowane w powiązaniu ze strefą wejściową lub przestrzenią dzienną, nie powinny natomiast ingerować w strefy rodziców i dzieci. 


\section{ERGONOMIA WNĘTRZ}

Szczegółowa analiza parametrów przestrzennych poszczególnych pomieszczeń pozwala na określenie możliwości ich aranżacji meblowej w sposób zadawalający potencjalnego nabywcę mieszkania. Niezbędna jest przy tym posługiwanie się gabarytami współcześnie produkowanych mebli oraz od dawna zdefiniowanymi polami ich obsługi (dostępności). Szczegółowej ocenie podlegają parametry przestrzenne poszczególnych pomieszczeń (określenie ich prawidłowej wielkości) oraz wygoda ich użytkowania. Pomieszczenia te na potrzeby prowadzonych badań zgrupowano w blokach odpowiadających zdefiniowanym powyżej strefom funkcjonalnym:

Część wejściowa, która obejmuje hall wejściowy, garderobę i WC wymaga kontroli i oceny poszczególnych pomieszczeń.

Hall powinien umożliwić swobodną komunikację w tym osoby na wózku inwalidzkim (okrągłe pole o średnicy $150 \mathrm{~cm}$ w bezpośrednim sąsiedztwie drzwi wejściowych). Powierzchnia ta zapewnia swobodę przy ubieraniu okryć zewnętrznych oraz zapewnia możliwość zmieszczenia kilku osób. Hall powinien dawać możliwość zmieszczenia szafki (półki) z telefonem (blatu odkładczego) oraz siedziska.

Garderoba przy wejściu powinna dawać możliwość jej dzielenia na część przeznaczoną wyłącznie dla domowników (okrycia wierzchnie, buty, czapki, szaliki, rękawiczki) oraz gości i sporadycznie mieszkańców (wieszak lub otwarta szafa). Garderoba powinna być wyposażona w lustro umożliwiające obejrzenie całej sylwetki zaś sposobem jej rozwiązania mogą być szafy w pomieszczeniu hallu lub zintegrowane z nim pomieszczenie. Pomieszczenie to częstokroć jest wykorzystywane jako przestrzeń magazynowa oraz gospodarcza i porządkowa.

WC zlokalizowany przy wejściu powinien być wyposażony w miskę ustępową i umywalkę. Pożądanym elementem wyposażenia jest blat umożliwiający odstawienie torebki. Pomieszczenie to może być zintegrowane $\mathrm{z}$ domową pralnia lub pomieszczeniem porządkowym.

Część dzienna i kuchnia to pomieszczenia reprezentacyjne, więc komfort ich użytkowania związany jest z przestrzennością, w tym swoistym „luzem” przestrzennym (powierzchnia większa niż wynika z uwarunkowań ergonomicznych). W tej części mieszkania zlokalizowane są: aneks wypoczynkowy powiązany z telewizorem, aneks jadalny (jadalnia „odświętna”) oraz kuchnia.

Aneks wypoczynkowy przestrzennie powinien być zorganizowany w taki sposób by zapewniał ilość siedzisk większą niż liczba domowników. Znacząca część siedzisk powinna być usytuowana w sposób umożliwiający korzystającym z nich osób „kontrolę” nad wejściem do pomieszczenia, zaś wszystkim możliwość oglądania telewizora (organizacja jego miejsca wymaga analizy sytuowania odbiornika TV). W tej części mieszkania muszą znaleźć miejsce urządzenia multimedialne związane $\mathrm{z}$ telewizorem.

Aneks jadalny powinien mieścić stół przeznaczony dla domowników oraz meble umożliwiające przechowywanie nakryć i bielizny stołowej (kredensy, komody). Pożądanym rozwiązaniem jest zapewnienie miejsca na mebel o przeznaczeniu odstawczym (blat, stół, komoda). Ze względy na możliwość przyjmowania większej liczby gości, przestrzeń związana ze stołem powinna dawać możliwość rozkładania go zaś w mieszkaniu muszą się znaleźć dodatkowe krzesła, które będą wykorzystywane przy takiej okazji.

Kuchnia zgodnie z warunkami technicznymi musi dawać możliwość wyposażenia w podstawowy sprzęt AGD oraz umożliwiać przyrządzanie posiłków. Zasadne wydaje się być wyposażenie współczesnej kuchni w: lodówkę (o wielkości odpowiadającej wielkości rodziny lub zaspokajającej potrzeby prestiżowe właścicieli - lodówka szerokości $90 \mathrm{~cm}$ powszechnie uważana jest za „lepszą”, „bardziej nowoczesną”), zlewozmywak (o wielkości skorelowanej z ilością zmywanych naczyń - ilością mieszkańców), zmywarkę do naczyń (do wbudowania pod blatem w sąsiedztwie zlewozmywaka, o szerokości 45 lub $60 \mathrm{~cm}$, w zależności od ilości mieszkańców), płytę grzewczą na blacie roboczym (o szerokości minimum $60 \mathrm{~cm}$ ) oraz 
piekarnik umieszczany w zabudowie na wysokości rąk (szerokość $60 \mathrm{~cm}$ ). Ponadto w zabudowie mogą zostać zlokalizowane: piekarnik parowy, kuchnia mikrofalowa, ekspres do kawy - każde o szerokości $60 \mathrm{~cm}$. Urządzenia te powinny być ustawione w odpowiedniej kolejności wynikającej z kolejności pracy oraz oddzielone odpowiedniej długości blatami roboczymi. Ilość blatów roboczych (ich długość) powinna wynikać z uwarunkowań ergonomicznych być związana z liczbą mieszkańców, przy jednoczesnym zachowaniu zasad trójkąta pracy. Współczesne kuchnie coraz częściej projektowane są jako pomieszczenia wyposażone w „wyspę” - mebel ustawiany na środku pomieszczenia. Możliwość jego zastosowania współcześnie stanowi niewątpliwy atut kuchni. W pomieszczeniu tym powinno być możliwe spożywanie szybkich rodzinnych posiłków, a w związku z tym konieczne jest zmieszczenie stołu lub odpowiednio zaprojektowanego baru (opcjonalnie miejsca przy „wyspie”). Kuchnia to również miejsce przechowywania naczyń kuchennych i stołowych, urządzeń mechanicznych używanych w kuchni, produktów spożywczych i środków czystości - wszystkie z nich muszą znaleźć swoje miejsce. Częstokroć w mieszkaniach dużych przechowywanie odbywa się w pomieszczeniach gospodarczych przyległych do kuchni. Pełnią one rolę spiżarni oraz współczesnych kredensów a niejednokrotnie pomieszczeń gospodarczych - pralni.

Strefa rodziców to ich prywatna część mieszkania. W jej skład wchodzą: sypialnia, garderoba a w mieszkaniach dużych dodatkowo łazienka. Sypialnia rodziców, nazywana również sypialnią główną, to najbardziej standardowo wyposażone pomieszczenie w mieszkaniu. Powinno się w nim zmieścić dwuosobowe łóżko, które będzie dostępne $\mathrm{z}$ trzech stron, szafki nocne, mebel na którym można odłożyć szlafrok ale również narzutę z łóżka (krzesło, fotel, ławka, kozetka). Rozwiązaniem pożądanym jest zmieszczenie w tym pomieszczeniu toaletki umożliwiającej wykonanie makijażu oraz telewizora, usytuowanego tak, by można było go oglądać w pozycji leżącej na łóżku. Analizując aranżację meblową tego pomieszczenia należy pamiętać, iż łóżko nie powinno stać w przeciągu (na linii drzwi - okno), zaś osoba leżąca na łóżku powinna widzieć wchodzących do pokoju („kontrolować” wejście).

Garderoba związana z sypialnią rodziców może być rozwiązana w formie szaf wbudowanych $\mathrm{w}$ sypialni (opcjonalnie w przedpokoju lub pobliskim korytarzu) lub odrębnego pomieszczenia (odrębnych pomieszczeń pani i pana domu). Ilość szaf (wielkość garderoby) wynika $\mathrm{z}$ indywidualnych potrzeb użytkowników. Pamiętać przy tym należy, że w latach 70 . obowiązywał wskaźnik $90 \mathrm{~cm}$ bieżących na jedną osobę. Analizując sposób aranżacji tej strefy należy zwrócić szczególną uwagę na to, czy nie powoduje ona „wpadania na meble” czyli wchodzenia na ściany szczytowe szaf i komód.

Łazienka główna, łazienka rodziców to największa i najlepiej wyposażona łazienka w mieszkaniu. Współczesny standard wskazuje, że w pomieszczeniu tym powinny znaleźć się: wanna (często narożna, niekiedy wyposażona w system hydromasażu), kabina natryskowa (częstokroć z opcją masaży wodnych), miska ustępowa, bidet, dwie umywalki, szafki na kosmetyki i ręczniki. Standard wyposażenia tej łazienki częstokroć w zasadniczy sposób wpływa na określenie standardu całego mieszkania.

Strefa dzieci to zespół ich indywidualnych pokoi, garderoba i łazienka. W przeciwieństwie do strefy rodziców, która wyposażana jest w sposób standardowy, strefa dzieci ulega ciągłym przeobrażeniom. Wynika to ze zmieniających się wraz z wzrostem potrzeb użytkowników tej strefy oraz chęci samo decydowania o otaczającej przestrzeni. Dobrze zaprojektowany pokój dziecka powinien dawać możliwość ustawienia: jednoosobowego łóżka (szerokości $90 \mathrm{~cm}$ ) w kilku położeniach, wariantowego sytuowania biurka z prawidłowym oświetleniem światłem dziennym (z lewej strony lub na wprost) oraz regałów służących do przechowywania zabawek i/lub książek a ponadto szafy ubraniowej. W mieszkaniach dużych szafy dzieci lokalizowane są w przestrzeniach korytarzy stanowiących komunikację wewnętrzną lub specjalnie wydzielonych garderobach. W przypadku wydzielonej łazienki dla dzieci zwykle bywa ona wyposażona w wannę lub kabinę prysznicową, miskę ustępową i umywalkę oraz meble łazienkowe. 
Tabela 1. Schemat zestawienia kryteriów oceny jakości użytkowej mieszkania

Table 1. Scheme of criteria compilation of usable home quality

\begin{tabular}{|c|c|c|c|c|c|c|c|}
\hline \multicolumn{8}{|l|}{ PRAWO BUDOWLANE } \\
\hline \multicolumn{3}{|c|}{$\begin{array}{l}\text { warunki oczywiste } \\
\text { wszystkie warunki muszą spełniać minima } \\
\text { wynikające z warunków technicznych }\end{array}$} & \multicolumn{3}{|c|}{$\begin{array}{l}\text { warunki niezbędne } \\
\text { wszystkie warunki muszą spełniać } \\
\text { minima wynikające z warunków tech- } \\
\text { nicznych, poszczególne z nich mogą być } \\
\text { skalowane i wpływać na podwyższenie } \\
\text { oceny mieszkania }\end{array}$} & \multicolumn{2}{|c|}{$\begin{array}{l}\text { warunki mogące podwyż- } \\
\text { szyć ocenę mieszkania } \\
\text { ocena skalowa, wpływa- } \\
\text { jąca na podwyższenie } \\
\text { oceny mieszkania }\end{array}$} \\
\hline \multicolumn{3}{|c|}{$\begin{array}{l}\text { - wydzielenie przeciwpożarowe } \\
\text { - ewakuacja } \\
\text { - minimalna wielkość otworów okiennych } \\
\text { i drzwiowych } \\
\text { - wentylacja } \\
\text { - nasłonecznienie } \\
\text { - minimalne wyposażenie sanitarne }\end{array}$} & \multicolumn{3}{|c|}{$\begin{array}{l}\text { - zachowanie gabarytów sparametryzo- } \\
\text { wanych (komunikacja, pokoje, kuchnia, } \\
\text { wysokość pomieszczeń) }\end{array}$} & \multicolumn{2}{|c|}{$\begin{array}{l}\text { - wysokość mieszkania } \\
\text { - nasłonecznienie } \\
\text { - strefa zewnętrzna } \\
\text { - przewietrzanie }\end{array}$} \\
\hline \multicolumn{8}{|c|}{ KSZTAŁTOWANIE PRZESTRZENI } \\
\hline \multicolumn{8}{|c|}{$\begin{array}{l}\text { Poziom ogólny - odnoszący się do całego mieszkania } \\
\text { Ocenie podlega prawidłowość rozwiązania układu przestrzennego w korelacji z wielkością mieszkania i zało- } \\
\text { żonym programem funkcjonalnym. Oceniany jest: - wybór układu (według założonej gradacji), prawidłowość } \\
\text { konkretnego rozwiązania projektowego (według założonego skalowania ocen). }\end{array}$} \\
\hline Układ amfiladowy & \multicolumn{2}{|c|}{ open space } & \multicolumn{2}{|c|}{ Układ rozkładowy } & $\begin{array}{l}\text { Układ } \\
\text { z podziałem } \\
\text { na strefy } \\
\text { funkcjonalne }\end{array}$ & $\begin{array}{l}\text { Układ } \\
\text { cyrkulacyjny }\end{array}$ & $\begin{array}{l}\text { Układ } \\
\text { dwupo- } \\
\text { ziomowy }\end{array}$ \\
\hline \multicolumn{8}{|c|}{ Mieszkanie typu studio i penthouse wymagają zindywidualizowanego schematu oceny układu przestrzennego. } \\
\hline \multicolumn{8}{|c|}{$\begin{array}{l}\text { Poziom szczegółowy - odnoszący się do poszczególnych zdefiniowanych stref funkcjonalnych } \\
\text { Ocenie podlega prawidłowość rozwiązania układu przestrzennego poszczególnych części (stref) mieszkania. } \\
\text { Każda z części oceniana jest odrębnie według założonego skalowania ocen. Waga ocen poszczególnych części } \\
\text { musi być zróżnicowana i uzależniona od znaczenia w układzie mieszkania, zasadne wydaje się być różnico- } \\
\text { wanie uzależniające wartość wagi od wielkości mieszkania. Łączna maksymalna ocena poszczególnych części } \\
\text { każdorazowo musi składać się na 100\% - wartościowanie poszczególnych części uzależnione będzie od wielkości } \\
\text { mieszkania. }\end{array}$} \\
\hline część wejściowa & część dz & zienna & kuchnia & $\begin{array}{l}\text { strefa } \\
\text { rodziców }\end{array}$ & strefa dzieci & $\begin{array}{l}\text { strefa } \\
\text { gospodar- } \\
\text { cza }\end{array}$ & $\begin{array}{l}\text { strefa } \\
\text { programu } \\
\text { dodatko- } \\
\text { wego }\end{array}$ \\
\hline $\begin{array}{l}\text { wydzielenie przestrzenne } \\
\text { z układu mieszkania }\end{array}$ & $\begin{array}{l}\text { podział } \\
\text { na anek } \\
\text { funkcjor } \\
\text { (użytko }\end{array}$ & $\begin{array}{l}\text { ssy } \\
\text { nalne } \\
\text { we) }\end{array}$ & $\begin{array}{l}\text { stopień powią- } \\
\text { zania z pokojem } \\
\text { dziennym }\end{array}$ & $\begin{array}{l}\text { wydzie- } \\
\text { lenie } \\
\text { funk- } \\
\text { cjonalne } \\
\text { i odizo- } \\
\text { lowanie } \\
\text { od części } \\
\text { dziennej }\end{array}$ & $\begin{array}{l}\text { wydzielenie } \\
\text { funkcjonalne } \\
\text { i odizolowan } \\
\text { od części } \\
\text { dziennej }\end{array}$ & $\begin{array}{l}\text { wydzie- } \\
\text { lenie } \\
\text { funk- } \\
\text { cjonalne } \\
\text { i prze- } \\
\text { strzenne }\end{array}$ & $\begin{array}{l}\text { wydzie- } \\
\text { lenie } \\
\text { funk- } \\
\text { cjonalne } \\
\text { i prze- } \\
\text { strzenne }\end{array}$ \\
\hline \multicolumn{8}{|c|}{$\begin{array}{l}\text { ERGONOMIA WNĘTRZ } \\
\text { Ocenie podlega ergonomia każdego z wnętrz (wydzielonych aneksów funkcjonalnych). Łączna maksymalna } \\
\text { ocena poszczególnych pomieszczeń każdorazowo musi składać się na } 100 \% \text { - wartościowanie poszczególnych } \\
\text { elementów uzależnione będzie od wielkości mieszkania. }\end{array}$} \\
\hline część wejściowa & $\begin{array}{l}\text { część } \\
\text { dzienna }\end{array}$ & kuchnia & strefa rodziców & & strefa dzieci & $\begin{array}{l}\text { strefa } \\
\text { gospodarcza }\end{array}$ & $\begin{array}{l}\text { strefa } \\
\text { programu } \\
\text { dodatko- } \\
\text { wego }\end{array}$ \\
\hline
\end{tabular}




\begin{tabular}{|c|c|c|c|c|c|c|}
\hline $\begin{array}{l}\text { - hall } \\
\text { - garderoba } \\
\text { - WC }\end{array}$ & $\begin{array}{l}\text { - aneks } \\
\text { wypo- } \\
\text { czyn- } \\
\text { kowy } \\
\text { - aneks } \\
\text { jadalny }\end{array}$ & \begin{tabular}{|l} 
- układ \\
prze- \\
strzenny \\
strefy \\
roboczej \\
- aneks \\
jadalnia- \\
ny \\
- spiżar- \\
nia
\end{tabular} & $\begin{array}{l}\text { - sypialnia rodziców } \\
\text { - garderoba } \\
\text { - łazienka główna }\end{array}$ & $\begin{array}{l}\text { - pokoje dzieci } \\
\text { - łazienka } \\
\text { dzieci }\end{array}$ & $\begin{array}{l}\text {-pomiesz- } \\
\text { czenia } \\
\text { magazynowe } \\
\text { - pomiesz- } \\
\text { czenia } \\
\text { porządkowe } \\
\text { - pralnia }\end{array}$ & $\begin{array}{l}\text { - pokoje } \\
\text { gościnne } \\
\text { - pokoje } \\
\text { do pracy } \\
\text { - służ- } \\
\text { bówka }\end{array}$ \\
\hline
\end{tabular}

Mieszkania wyposażone w schody wewnętrzne wymagają zindywidualizowanego schematu oceny klatki schodowej w podziale na takie elementy, jak: funkcja (ergonomia), estetyka (ekspozycja).

Strefa gospodarcza we współczesnym mieszkaniu bywa podzielona na części: magazynowe, porządkowe, pralnię. Realizowane są one odrębne pomieszczenia lub meble wbudowane w pomieszczeniach komunikacyjnych, garderobach i łazienkach. Szczególną uwagę w tym obszarze należy zwrócić na pralkę i suszarkę do bielizny które stają się elementem, wpływającym na standard wyposażenia mieszkań.

Strefa programu dodatkowego to pokoje gościnne i pokoje do pracy. Ergonomia ich wyposażenia w znacznym stopniu uzależniona jest od sposobu użytkowania, a wpływ na nią może mieć sytuowanie drzwi wejściowych. Pomieszczenia te każdorazowo wymagają oceny indywidualnej. Podobnie jest w przypadku tak zwanych służbówek - pokoi mieszkalnych przeznaczonych dla pomocy domowych, stale mieszkających w mieszkaniu.

W mieszkaniach dwupoziomowych ocenie podlega również ergonomia (wygoda użytkowa) klatki schodowej.

\section{ZESTAWIENIE ZDEFINIOWANYCH KRYTERIÓW}

Złożoność problemu oceny cech i parametrów mieszkań, które zdefiniowano powyżej wskazuje na potrzebę budowy stosownego narzędzia pomiarowego. W zamieszczonej poniżej Tabeli 1. zestawiono poszczególne omawiane cechy i parametry, a ich grupy opatrzono stosownymi (możliwymi do zdefiniowania na obecnym etapie prac badawczych) uwagami metodologicznymi.

Analiza powyższego zestawienia prowadzi do wniosków, iż pożądane narzędzie pomiarowe, które powinno wartościować (ustawiać w porządku według skalara wartości w porządku hierarchicznym) konkretne mieszkania, wymaga dalszych prac badawczych. Ich kolejny etap powinien polegać na działaniach matematycznych związanych z wykorzystaniem analiz wielokryterialnych. Działania te powinny być połączone z pracami empirycznymi i kontrolowaniem całego procesu z pozycji ocen eksperckich.

\section{PODSUMOWANIE}

Zaprezentowane powyżej uwarunkowania kształtowania współczesnego środowiska mieszkaniowego wskazują na potrzebę poszukiwania metod jego oceny i wartościowania. Próba zdefiniowania sposobu wartościowania jakości użytkowej współczesnego mieszkania (jakości odpowiadającej potrzebom współczesnego użytkownika) pozwoliła na zdefiniowanie zestawu cech i parametrów mieszkań, które powinny podlegać ocenie. Analiza uzyskanych wyników potwierdza wysoki stopień skomplikowania zagadnienia i wskazuje na potrzebę skorzystania ze zobiektywizowanych metod matematycznych.

Ponadto, jak przedstawiono to powyżej, prowadzone obecnie prace badawcze poza aspektem użytkowym jak? mieszkać dotyczą aspektów: gdzie?, za ile? i dlaczego?, które to w niniejszym opracowaniu były wyłącznie sygnalizowane. 


\title{
PIŚMIENNICTWO
}

Alexander Ch., 2008. Język wzorców, Gdańskie Wydawnictwo Psychologiczne, Gdańsk

Goryński J., 1973. Mieszkanie wczoraj dziś i jutro, Wiedza Powszechna, Warszawa.

Grandjean E,. 1978. Ergonomia mieszkania - aspekty fizjologiczne i psychologiczne w projektowaniu, Arkady, Warszawa.

Jezierski B. J., 1983. Zamość Nowe Miasto [w:] Architektura (412) marzec - kwiecień.

Korzeniewski W., 1987. Podstawy projektowania mieszkań i budynków wielorodzinnych, Centralny Ośrodek Informacji Budowlanej, Warszawa.

Korzeniewski W., 1989. Budownictwo mieszkaniowe. Poradnik Projektanta, Arkady, Warszawa.

Korzeniewski W., 2011. Projektowanie mieszkań, Oficyna Wydawnicza POLCEN spółka z o.o., Warszawa.

Łącki S., Malicka W., Malicki Z., 1961. Budownictwo mieszkaniowe, ARKADY, Warszawa.

Maass J., Referdowska M., 1965. Mieszkanie, Arkady, Warszawa.

Mieszkowski Z., 1980. Mieszkanie. Elementy i zespoły, Politechnika Krakowska, Kraków.

Neufert E., 2003. Poradnik projektowania architektoniczno - budowlanego, Arkady, Warszawa.

Pallado J., 2014. Zabudowa wielorodzinna. Podstawy projektowania, Wydawnictwo Politechniki Śląskiej, Gliwice.

Piechotkowie M. i K., 1966. Tendencje rozwojowe w ksztaltowaniu mieszkań w Polsce Ludowej [w:] Studia nad rozwojem mieszkalnictwa, Państwowe Wydawnictwo Naukowe, Warszawa.

Piliszka E. (red. nauk.), 1974. Systemy budownictwa mieszkaniowego i ogólnego, ARKADY, Warszawa.

Płażewska M., Terlikowski R., 1989. Współczesne mieszkanie, Arkady.

Rosner J., 1985. Ergonomia, Państwowe Wydawnictwo Ekonomiczne, Warszawa.

Rozporządzeniu Ministra Infrastruktury w sprawie warunków technicznych, jakim powinny odpowiadać budynki i ich usytuowanie z dnia 12 kwietnia 2002 r. z późniejszymi zmianami, (Dz.U. Nr 75, poz. 690).

Rybczyński W., 1996. Dom. Krótka historia idei, Marabut - Volumen, Gdańsk - Warszawa.

Skibniewska H., 1974. Rodzina a mieszkanie, Państwowe Wydawnictwo Naukowe, Warszawa.

Szymański J., 1975. Książka o mieszkaniu, Instytut Wydawniczy CRZZ, Warszawa.

Włodarczyk J.A., 1997. Żyć znaczy mieszkać. Dom naszych pragnień i możliwości, Wydawnictwo Naukowe PWN, Warszawa-Kraków.

Woydowie T., T., 1990. Jak urządzić mieszkanie, Arkady, Warszawa.

Wykowska M., 1994. Ergonomia, Wydawnictwo AGH, Kraków.

\section{HOW TO EVALUATE THE CONTEMPORARY FLAT? ATTEMPT TO DEFINE CRITERIA ASSESSING THE FUNCTIONAL QUALITY OF CONTEMPORARY POLISH FLAT}

\begin{abstract}
In the article a current problem was presented - of functional quality assessment of contemporary flats. These issues were clarified relating to experience design and connected with realization of several dozen last years. Towards the lack of objective methods of estimation and assessing discussed issues the author shows criteria being able to become a base of such touchstones and evaluations.
\end{abstract}

Keywords: flat, quality of the space, quality of the flat, usefulness of the flat 